\title{
Ownership Structure and Earnings Forecast Accuracy: Evidence from Malaysian IPOs
}

\author{
Noor Ayuernie Ibrahim and Norashikin Ismail
}

\begin{abstract}
This study investigates the association of different types of ownership structure and the forecast accuracy in the context of mandatory earnings forecasts disclosure requirement. The analysis was tested on a sample of 185 IPO prospectuses published from January 2001 to $30^{\text {th }}$ April 2008. With the mean forecast errors of $\mathbf{- 6 . 3 0}$ percent and absolute forecast error (AFE) of 22.11 percent, the result indicates that on average, Malaysian IPO companies issue optimistic and less accurate earnings forecast. Using ordinary least square (OLS) regression, this study suggests that the institutional and active-family ownership are positively associated with forecast accuracy, while management ownership is negatively associated with forecast accuracy.
\end{abstract}

Index Terms-Forecast accuracy, forecast errors, ownership structure, and initial public offerings.

\section{INTRODUCTION}

The study of forecast accuracy at the time of initial public offerings (IPOs) have focused on internal factor of management optimism [1] as well as other external factors of economic condition and regulation [2]. Most existing evidence on the research question of interest indicates the levels of forecast accuracy is being affected by the changes in economic condition [2] and on average companies are reluctant to forecast a decline in earnings [1]. The current study seeks to contribute to literature by re-examining the issue focusing on the impact of different types of ownership on the accuracy of forecast. The Malaysian setting is characterized by not only ownership concentration per se [3], but according to [4] with low litigious environment of shareholders protection. These are significant features of Malaysian companies that distinguish the statues of agency problem from those of developed countries. Given the difference in ownership structure, legal system and institutional environment between developed and developing countries, this study attempts to investigate the association of ownership structure and the accuracy of earnings forecast reported in the prospectus of Malaysian IPOs.

The issue of forecast accuracy in Malaysia is quite an alarming as Malaysian Securities Commission (SC) reported that 72 percent of 29 newly-listed companies in year 2005 have been reported failed to meet the earnings forecast made in their prospectuses and out of the 21 IPOs, 15 companies showed deviations exceeding 20 percent [5]. The inaccuracy of forecast made may affect the credibility of forecast figure for reducing the information asymmetry in the IPO process.

Manuscript received September 2, 2013; revised November 11, 2013.

The authors are with the Faculty of Accountancy, Universiti Teknologi MARA, Malaysia (e-mail: noor_ayuernie@yahoo.com, shikin673@salam.uitm.edu.my).
Extending prior study which concludes that management optimism and economic condition are significantly influenced the accuracy of forecast [2], this study examines whether types of ownership concentration has an influence on the accuracy of forecast. Our findings indicate, type of ownership concentration affects the accuracy of forecast and in particular, the findings provide evidence that higher percentage of shares owned by active-family and institutions resulted in greater accuracy of forecasts. This result is in contradiction to the relationship between forecast accuracy and management ownership. The result shows a positive association between the percentage of shares owned by management and accuracy. This indicates that the greater is the percentage of shares owned by managers, the greater is the difference between actual and forecasted earnings. This positive relationship is perhaps due to the managers' optimism in forecasting consistent with [2].

The remainder of the paper is organized as follow. First, previous literature is reviewed in Section II. Section III describes the research methodology employed by this study. Section IV reports the analyses and results of study. Finally, a summary of the findings and conclusion of the study are presented in Section V.

\section{LITERATURE REVIEW}

Prior evidence on the accuracy of earnings forecasts provided in IPO prospectuses suggests that managements are in general over-optimistic in their forecasts, with IPO companies consistently failing to achieve earnings forecast targets in their first year of operation [6]-[8]. The result of studies in New Zealand [9] and Canada [10] were found to be significantly less accurate compared to the results documented in Malaysia [2], Singapore [11] and Taiwan [12]. [1] and [13] suggested that managers in Malaysian IPOs in general are cautious forecasters because of strict regulation of IPOs in Malaysia and the fact that managers are personally accountable to the SC for their forecasts. On the factors determining accuracy, [2] documented evidence that the forecast accuracy is influenced by economic conditions, while [14] find no association between governance and the accuracy of forecasts.

In the context of different types of ownership, prior works examining the link between type of ownership structure and earnings forecast disclosure tends to focuses either on the institutional ownership [15], [16], management ownership [6], [17], or equity retained by owners [7], [8], [18] separately and found no relationship between ownership type and the accuracy of forecasts. This study on the other hand examines the impact of various ownership types including active-family ownership on the accuracy. 


\section{RESEARCH METHODOLOGY}

\section{A. Sample Selection}

The sample of this study consists of Malaysian newly listed companies from January 2001 to $30^{\text {th }}$ April 2008. The examined period ends on $30^{\text {th }}$ April taking into consideration that beginning May 2008, all Malaysian IPO companies are not subjected to mandatory disclosure of earnings forecast in their prospectus [19].

There are a total of 225 IPOs made during the period. Out of 225 companies, four companies in the finance industry sector were excluded due to the differences in regulatory oversight governing their practices on financial reporting disclosures. A further 20 companies from several sectors are eliminated due to the small number of population in the respective sectors. Among the sectors are infrastructure project companies (IPC), real estate investment trusts (REITs), technology and closed-end funds. Another 16 companies were excluded for the reasons of unavailability of annual report, companies that have changed their financial year end date and outliers. Earnings are taken on a before tax basis. The final sample consists of 185 IPO companies. All company's prospectuses and annual reports were obtained either from the website of Bursa Malaysia or respective company's website.

\section{B. Measurement of Variables \\ 1) Measurement of forecast accuracy}

Forecast accuracy is measured in terms of the relative magnitude of the difference between forecasted and actual earnings. It provides an indication of how close the forecasts were to actual profits in absolute terms. It is measured as absolute forecast error (AFE), and computed as follows:

$$
\begin{aligned}
& \text { Absolute Forecast Error }{ }_{i, t} \\
& =\frac{\mid \text { Actual Earning }_{i, t}-\text { Forecast Earning } s_{i, t} \mid}{\mid \text { Forecast Earning }_{i, t} \mid} \times 100
\end{aligned}
$$

\section{2) Measurement of independent variables}

Measurement of different ownership type (i.e. institutional, management and active-family ownership) is defined in Table I Other variables of size, leverage, company age and forecast horizon are included as control variables.

TABLE I: MEASUREMENT OF INDEPENDENT VARIABLES

\begin{tabular}{ll}
\hline Variables & \multicolumn{1}{c}{ Measurement } \\
\hline Institutional Ownership & $\begin{array}{l}\text { The percentage of common shares owned by the following organizations such as insurance } \\
\text { companies (life and non-life), superannuation and pension funds, investment trusts (including } \\
\text { unit trusts), financial institutions (including banks and banks nominee companies, finance } \\
\text { companies, building societies and credit cooperatives), investment companies, and other nominee } \\
\text { companies associated with the above categories of institutions. }\end{array}$ \\
\hline Management Ownership & The percentage of common shares directly owned by executive directors. \\
\hline $\begin{array}{l}\text { Active- } \\
\text { Ownership }\end{array}$ & $\begin{array}{l}\text { The proportion of total common shares directly owned by founding family and/or the presence of } \\
\text { family members on the board of directors to identified family. }\end{array}$ \\
\hline Company Size & Total assets before listing. \\
\hline Leverage & Long-term debt divided by total assets. \\
\hline Company Age & $\begin{array}{l}\text { Length of operating history measured as number of years since the company had been in } \\
\text { existence. }\end{array}$ \\
\hline
\end{tabular}

Data for ownership structure were obtained from the first annual report released after the listing, while all data for the company characteristics was manually obtained from the company's prospectus.

\section{RESULTS AND DISCUSSION}

To investigate the association between the accuracy of profit forecast and various ownership concentrations, an Ordinary Least Square (OLS) regression model was adopted in the analysis, transforming the dependent variable by normalization [20]. The OLS regression model is defined by the following equation:

$A F E_{i}=\beta_{0}+\beta_{1}$ InstO $n_{i}+\beta_{2}$ MgmtOwn $_{i}+\beta_{3}$ ActFamOwn $_{i}+$ $\beta_{4}$ Size $_{i}+\beta_{5}$ Lev $_{i}+\beta_{6}$ Age $_{i}++\beta_{7}$ Horizon $_{i}+\varepsilon_{i}$

where

$\mathrm{AFE}=$ Absolute Forecast Errors;

Inst Own = Institutional Ownership;

Mgmt Own = Management Ownership;

Act Fam Own = Active-Family Ownership;

Size = Company Size;

Lev = Leverage;

Age = Company Age;
Horizon = Forecast Horizon;

$B=$ Regression Coefficient;

$\varepsilon=$ Standard Error Term of OLS Regression;

$i=$ Number of Companies.

Table II presents the descriptive statistics for the dependent variable. Descriptive statistics for the dependent variable of absolute forecast error (AFE) indicates that IPO companies for the period of studies are less accurate in their forecast with an absolute forecast error of 22.1 percent, a minimum of 0.08 percent and a maximum of 94.84 percent. Parametric one-sample $t$ test and non-parametric Wilcoxon signed rank test show that the difference between forecast and actual earnings is significant at the 1 percentage level. The absolute forecast error is however lower than the result reported by [2] in their study of 64 Malaysian IPOs during economic recovery period ( $\mathrm{AFE}=26.35$ percent $)$ and higher than the same market IPOs during the crisis period (AFE = 31.56 percent, $n=65$ ). Comparatively, the mean absolute forecast error is 42.82 percent for Greece forecasts [7], 163.4 percent for Jordanian forecasts [21], 49.05 percent for Indonesia forecasts [22], and 35.76 percent for Thailand forecasts [23]. Finding by this study suggests that Malaysian IPO forecast accuracy is at moderate level compared to other countries.

The descriptive statistic concerning forecast errors 
presented in Table II shows that, in average the earnings forecast exceeded earnings realized ( -6.30 percent). This finding indicates that there is some optimism from Malaysian IPO companies. The manager could be incited to issue optimistic earnings forecasts in interest of pre-IPO shareholders, on the basis of the expected growth of the results to obtain a better price for the sold securities and to attract more potential investors. Comparatively, the mean forecast errors for the period of present study is much lower compared to forecast error reported by [2]. The higher forecast error of -14.12 percent reported by [2] however can be explained by the data covering the period during economic crisis. Contrary, this finding differs significantly from the reported empirical findings of [1], [13], [24], [25] as they are reported a positive mean forecast error.

TABLE II: DESCRIPTIVE STATISTIC OF FORECAST ERROR AND ABSOLUTE FORECAST ERROR

\begin{tabular}{|c|c|c|c|c|c|c|c|c|c|c|}
\hline & \multirow{2}{*}{$\begin{array}{l}\text { Mean } \\
(\%)\end{array}$} & \multirow{2}{*}{$\begin{array}{c}\text { Median } \\
(\%)\end{array}$} & \multirow{2}{*}{$\begin{array}{l}\text { Min } \\
(\%)\end{array}$} & \multirow{2}{*}{$\begin{array}{c}\operatorname{Max} \\
(\%)\end{array}$} & \multicolumn{2}{|c|}{ One-Sample $t$-test } & \multicolumn{2}{|c|}{$\begin{array}{c}\text { Wilcoxon Signed } \\
\text { Rank Test }\end{array}$} & \multicolumn{2}{|c|}{ Sign Test } \\
\hline & & & & & $t$-statistic ${ }^{*}$ & $p$ value & $\begin{array}{c}z \\
\text { value }\end{array}$ & Sig. value & $z$ value & $\begin{array}{l}\text { Sig. } \\
\text { value }\end{array}$ \\
\hline Forecast Errors & -6.30 & -2.99 & -94.84 & 79.01 & -2.791 & $0.006^{* * *}$ & -2.629 & $0.009^{* * *}$ & -2.353 & $0.019^{* * *}$ \\
\hline $\begin{array}{l}\text { Absolute } \\
\text { Forecast Errors }\end{array}$ & 22.11 & 11.93 & 0.08 & 94.84 & 13.565 & $0.000^{* * * *}$ & $\begin{array}{c}-11.79 \\
5\end{array}$ & $0.000^{* * * *}$ & -13.528 & $0.000^{* * *}$ \\
\hline
\end{tabular}

Note: *Test of significance that mean absolute forecast error is different from zero and denote significance at the 1 and 5 percent levels; respectively.

TABLE III: PARAMETRIC AND NON-PARAMETRIC TESTS OF COMPANIES WITH POSITIVE AND NEGATIVE FORECAST ERRORS

\begin{tabular}{|c|c|c|c|c|c|c|}
\hline & \multirow[t]{2}{*}{$\mathbf{n}$} & \multirow{2}{*}{$\begin{array}{c}\text { Mean } \\
\text { FE } \\
(\%)\end{array}$} & \multicolumn{2}{|c|}{$\begin{array}{c}\text { Independent Sample } \\
t \text {-test }\end{array}$} & \multicolumn{2}{|c|}{ Man-Whitney U test } \\
\hline & & & $t$-stat & $p$ value & $z$ value & $p$ value \\
\hline Positive FE & 76 & 19.24 & & & & \\
\hline Negative FE & 109 & -24.11 & 13.582 & $0.000^{* * * *}$ & -11.559 & $0.000^{* * * *}$ \\
\hline
\end{tabular}

Note: Result is significantly different from zero at the 1 percent level and 5 percent level, respectively, using two-tailed tests.

TABLE IV: PARAMETRIC AND NON-PARAMETRIC TESTS OF COMPANIES BY BOARD OF LISTING

\begin{tabular}{|c|c|c|c|c|c|c|}
\hline & \multirow{2}{*}{$\begin{array}{c}\text { Mean } \\
\text { FE } \\
(\%)\end{array}$} & \multirow{2}{*}{$\begin{array}{c}\text { Mean } \\
\text { AFE } \\
(\%)\end{array}$} & \multicolumn{2}{|c|}{$\begin{array}{l}\text { Independent } \\
\text { Sample } t \text {-test }\end{array}$} & \multicolumn{2}{|c|}{ Man-Whitney U Test } \\
\hline & & & $t$-stat & $p$ value & $z$ value & $p$ value \\
\hline $\begin{array}{l}\text { Main Board } \\
(n=71)\end{array}$ & -1.99 & 24.74 & \multirow[b]{2}{*}{1.279} & \multirow[b]{2}{*}{0.203} & \multirow[b]{2}{*}{-1.773} & \multirow[b]{2}{*}{0.076} \\
\hline $\begin{array}{l}\text { Second Board } \\
(n=114)\end{array}$ & -8.99 & 20.46 & & & & \\
\hline
\end{tabular}

Note: Result is significantly different from zero at the 1 percent level and 5 percent level, respectively, using two-tailed tests.

Table III presents the results of parametric and non-parametric tests for companies with positive and negative forecast errors.

The results presented in Table III show that out of 185 companies, only 76 or 41 percent of the sample companies with a mean of positive error while another 109 companies reported a negative mean forecast error. The result is significant at the 1 percent level.

Table IV reveals the results of parametric and non-parametric tests for IPO companies by board of listing. Although the mean forecast error of main board companies is close to zero, however, it cannot be concluded that the earnings forecast of these companies is accurate. Contrary to the main board companies, those companies listed on second board are more difficult to achieve their forecasts (mean forecast error $=-8.99$ percent), however, the result reveals that their forecast is more accurate compared to the main board. The results of both independent sample t-test and Man-Whitney $U$ test shows that there is no significance difference in the forecast accuracy between companies listed either in the main board or second board.

Table V presents' descriptive statistics on independent and control variables. The result shows that the mean institutional ownership is 11.04 percent and ranges from 0.00 to 86.98 percent with companies listed on the main board are on average having higher percentage of shares owned by institutional investors (mean $=12.35$ percent) than companies on the second board (10.23 percent). The higher percentage of institutional owners in the main board companies perhaps can be explained by the size and reputation of the companies that has attracted institution to invest.

In contrast, second board companies have higher percentage of shares in the hand of active-family and management. The largest active-family owner controls about 64.38 percent of the capital shares. The higher percentage of common shares in the hand of active-family and management perhaps can be explained by the fact that family and managers is the same people as suggested by [26]. He suggests that family members usually hold important positions on both the management team and the board of directors. These results are consistent with previous arguments which suggested that the ownership structure in East Asia companies is highly concentrated as compared to diffuse ownership structure in the US and the UK [27]. 
TABLE V: DESCRIPTIVE STATISTIC OF INDEPENDENT VARIABLES

\begin{tabular}{|c|c|c|c|c|c|c|c|c|c|}
\hline \multirow{2}{*}{ Variables } & \multicolumn{3}{|c|}{ Pooled Sample $(n=185)$} & \multicolumn{3}{|c|}{ Main Board $(n=71)$} & \multicolumn{3}{|c|}{ Second Board $(n=114)$} \\
\hline & Mean & Min & Max & Mean & Min & Max & Mean & Min & Max \\
\hline Institutional & & & & & & 86.98 & 10.23 & & 76.25 \\
\hline Ownership & 11.04 & 0.00 & 86.98 & 12.35 & 0.00 & & & 0.00 & \\
\hline Management & & & & & & 54.23 & 21.63 & & 61.34 \\
\hline Ownership & 17.97 & 0.00 & 61.34 & 12.09 & 0.00 & & & 0.00 & \\
\hline Active-Family & & & & & & 59.09 & 13.29 & & 64.38 \\
\hline Ownership & 10.87 & 0.00 & 64.38 & 6.98 & 0.00 & & & 0.00 & \\
\hline Company Size & & & & & & $16,796,338$ & 93,793 & & 383,173 \\
\hline$\left(\mathrm{RM}^{\prime} 000\right)$ & 310,243 & 37,425 & $16,796,338$ & 657,784 & 51,429 & & & 37,425 & \\
\hline Leverage (\%) & 10.35 & 0.00 & 71.88 & 13.56 & 0.00 & 71.88 & 8.3547 & 0.00 & 50.03 \\
\hline $\begin{array}{l}\text { Company Age } \\
\text { (years) }\end{array}$ & 19.01 & 3.00 & 49.00 & 19.52 & 4.00 & 49.00 & 18.69 & 3.00 & 42.00 \\
\hline Forecast & & & & & & 17.00 & 7.12 & & 18.00 \\
\hline $\begin{array}{l}\text { Horizon } \\
\text { (months) }\end{array}$ & 7.15 & 2.00 & 18.00 & 7.20 & 2.00 & & & 2.00 & \\
\hline
\end{tabular}

TABLE VI: CORRELATION BETWEEN FORECAST ACCURACY AND CONTINUOUS INDEPENDENT VARIABLES

\begin{tabular}{|c|c|c|c|c|c|c|c|c|}
\hline & $\begin{array}{c}\text { Absolute } \\
\text { Forecast Error }\end{array}$ & $\begin{array}{l}\text { Institutional } \\
\text { Ownership }\end{array}$ & $\begin{array}{c}\text { Management } \\
\text { Ownership }\end{array}$ & $\begin{array}{c}\text { Active-Family } \\
\text { Ownership }\end{array}$ & $\begin{array}{l}\text { Company } \\
\text { Size }\end{array}$ & Leverage & $\begin{array}{c}\text { Company } \\
\text { Age }\end{array}$ & $\begin{array}{l}\text { Forecast } \\
\text { Horizon }\end{array}$ \\
\hline $\begin{array}{l}\text { Absolute Forecast } \\
\text { Error }\end{array}$ & 1 & $\begin{array}{l}-0.105 \\
(0.155)\end{array}$ & $\begin{array}{c}0.032 \\
(0.663)\end{array}$ & $\begin{array}{l}-0.135^{*} \\
(0.068)\end{array}$ & $\begin{array}{l}-0.132^{*} \\
(0.074)\end{array}$ & $\begin{array}{c}0.012 \\
(0.874)\end{array}$ & $\begin{array}{l}-0.142^{*} \\
(0.054)\end{array}$ & $\begin{array}{l}0.175^{* * *} \\
(0.017)\end{array}$ \\
\hline $\begin{array}{l}\text { Institutional } \\
\text { Ownership }\end{array}$ & & 1 & $\begin{array}{l}-0.131 \\
(0.075)\end{array}$ & $\begin{array}{l}-0.184^{* *} \\
(0.012)\end{array}$ & $\begin{array}{l}0.174^{* *} \\
(0.018)\end{array}$ & $\begin{array}{c}0.012 \\
(0.872)\end{array}$ & $\begin{array}{l}-0.066 \\
(0.376)\end{array}$ & $\begin{array}{l}-0.010 \\
(0.892)\end{array}$ \\
\hline $\begin{array}{l}\text { Management } \\
\text { Ownership }\end{array}$ & & & 1 & $\begin{array}{c}0.543^{* * *} \\
(0.000)\end{array}$ & $\begin{array}{l}-0.136 \\
(0.065)\end{array}$ & $\begin{array}{l}-0.122 \\
(0.099)\end{array}$ & $\begin{array}{c}0.032 \\
(0.667)\end{array}$ & $\begin{array}{c}0.052 \\
(0.480)\end{array}$ \\
\hline $\begin{array}{l}\text { Active-Family } \\
\text { Ownership }\end{array}$ & & & & 1 & $\begin{array}{l}-0.085 \\
(0.250)\end{array}$ & $\begin{array}{l}-0.045 \\
(0.541)\end{array}$ & $\begin{array}{c}0.123 \\
(0.096)\end{array}$ & $\begin{array}{c}0.078 \\
(0.292)\end{array}$ \\
\hline $\begin{array}{l}\text { Company } \\
\text { Size }\end{array}$ & & & & & 1 & $\begin{array}{l}0.2566^{* * *} \\
(0.000)\end{array}$ & $\begin{array}{l}-0.034 \\
(0.647)\end{array}$ & $\begin{array}{l}-0.031 \\
(0.675)\end{array}$ \\
\hline Leverage & & & & & & 1 & $\begin{array}{l}-0.030 \\
(0.690)\end{array}$ & $\begin{array}{l}-0.086 \\
(0.245)\end{array}$ \\
\hline $\begin{array}{l}\text { Company } \\
\text { Age }\end{array}$ & & & & & & & 1 & $\begin{array}{l}0.147^{* *} \\
(0.047)\end{array}$ \\
\hline $\begin{array}{l}\text { Forecast } \\
\text { Horizon }\end{array}$ & & & & & & & & 1 \\
\hline
\end{tabular}

Note: Correlation is significant at 1 percent level, 5 percent level and $* 10$ percent level, respectively, using two-tailed tests.

Note: Correlation is significant at 5 percent level and 10 percent level, respectively, using two tailed tests.

${ }^{\text {a }}$ Normal score of absolute forecast error

Table VI presents the correlation analysis results between forecast accuracy and all continuous independent variables.

The result shows a positive correlation between forecast horizon and absolute forecast error $(r$ value $=0.175)$ at the 5 percent level. This result suggests that companies with longer forecast horizon are more difficult to forecast accurately. Furthermore, marginal negative significant correlations can be seen between active-family ownership, company size and company age. The negative correlation between active-family ownership and absolute forecast error ( $r$ value
$=-0.135)$ indicates that a higher active-family ownership resulted in higher forecast accuracy. All other independent variables have relatively weak correlations with the forecast accuracy.

Table VII presents the results of the multivariate regression.

The relationship between dependent variable of forecast accuracy and independent variables of different ownership types are examined using regression model. The result in Table VII shows that the model is significant at the one 
percentage level (1 percent) with an explanatory power of 10.20 percent. The possible threat of multicollinearity between independent variables is examined bu using the tolerance (TOL), variance inflation factors (VIFs), eigenvalue and condition index. Results reported in the Table
VII show that the TOL value is always more than .10 and the VIFs values are less than 2.0. In addition, the eigenvalue for all independent variables are not close to zero. These results suggests that there is no threat of multicollinearity.

TABLE VII: MULTIVARIATE REGRESSION RESULTS

\begin{tabular}{|c|c|c|c|c|c|c|c|c|}
\hline \multirow{2}{*}{$\begin{array}{l}\text { Independent } \\
\text { Variables }\end{array}$} & \multirow[t]{2}{*}{$\begin{array}{l}\text { Exp. } \\
\text { Sign }\end{array}$} & \multirow[t]{2}{*}{$\begin{array}{l}\text { Beta } \\
\text { Co-eff }\end{array}$} & \multirow[t]{2}{*}{$t$-statistic } & \multirow[t]{2}{*}{$p$ value } & \multicolumn{2}{|c|}{ Collinearity Statistics } & \multicolumn{2}{|c|}{ Collinearity Diagnostic } \\
\hline & & & & & Tolerance & VIF & Eigenvalue & $\begin{array}{l}\text { Condition } \\
\text { Index }\end{array}$ \\
\hline Institutional Ownership & \pm & -.155 & -2.166 & $.032^{* * *}$ & .950 & 1.053 & .941 & 2.492 \\
\hline Management Ownership & \pm & .171 & 2.001 & $.047^{* *}$ & .671 & 1.490 & .492 & 3.448 \\
\hline Active-family Ownership & \pm & -.299 & -2.704 & $.008^{* * * *}$ & .681 & 1.469 & .266 & 4.688 \\
\hline Company Size & \pm & .156 & 2.019 & $.045^{* *}$ & .817 & 1.224 & .247 & 4.865 \\
\hline Leverage & \pm & -.142 & -1.914 & .057 & .882 & 1.134 & .134 & 6.600 \\
\hline Company Age & \pm & -.157 & -2.201 & $.029^{* *}$ & .961 & 1.040 & .075 & 8.846 \\
\hline Forecast Horizon & \pm & .196 & 2.766 & $.006^{* * * *}$ & .970 & 1.031 & .041 & 16.191 \\
\hline Constant & & & -1.851 & $.066^{* *}$ & & & 5.845 & 1.000 \\
\hline$F$-value & & $3.989^{* * * *}$ & & & & & & \\
\hline R-square (\%) & & 13.60 & & & & & & \\
\hline Adj. R-square (\%) & & 10.20 & & & & & & \\
\hline$N$ & & 185 & & & & & & \\
\hline
\end{tabular}

Significant at the 0.05 level (2-tailed).

Note: Significant at the 0.01 level (2-tailed)

On the association between different ownership types and the accuracy of forecasts, the results show that the institutional and active-family ownership variables have significant association with accuracy. The negative association between the ownership types variables and absolute forecast error indicates that companies with higher active-family and institutional owners have low absolute forecast error and therefore, are more accurate in their forecast.

The result of negative associations between institutional ownership and absolute forecast error is consistent with the shared benefit hypothesis, where managers are more likely to issue accurate forecasts due to efficient monitoring by institutional investors. Consequently, the benefits of such monitoring are shared by all shareholders [28]. On the other hand, the result of negative associations between active-family ownership and absolute forecast error lend support to the reputation cost theory where managers are likely to issue more accurate forecast for the purpose of maintaining the reputations of the management and companies. The finding of this study is, however, in contrast with earlier results who found that in Taiwan, the active-family controlling owners tended to issue less accurate and more optimistically biased forecasts in the presence of greater control divergence [12].

Management ownership, on the other hand, is found to have a significant positive association with the absolute forecast error at the 5 percent level. This result suggests that IPO companies with a higher proportion of management ownership have lower forecast accuracy. The positive association between the proportion of shares held by the executive directors who legally hold the position in the board of directors and absolute forecast error is consistent with [17] $\&$ [29], who found that a higher proportion of ownership in
Malaysia and Australia IPO companies does not result in greater accuracy, respectively. Reference [17] suggested that, irrespective of economic conditions, the management tends to issue more optimistic forecasts.

Consistent with prior evidence, control variables of company size and forecast horizon are found to have a significant positive association with absolute forecast error [6], [8], [14], [23], [30], [31]. Company age on the other hand is found to have a positive association with absolute forecast error while there is no significant association is documented between leverage and absolute forecast error.

\section{CONClusion}

This study examines whether different types of ownership structure has an influence on the accuracy of IPOs earnings forecasts. Consistent with prior evidence, the results show that IPO companies in general are optimistic and less accurate in their forecast. On the association between ownership types and absolute forecast error, the results show that institutional and active-family ownerships are positively influence the accuracy of the forecast, while higher management owners impact negatively on the accuracy of forecast. The results on significant influence of institutional and active-family ownership on accuracy provides support for institutional monitoring hypothesis by institutional investors while the positive impact of active-family ownership on accuracy is in contrast to the results documented by [12]. On the other hand, the result of positive association between management ownership and absolute forecast error is in contrast to the reputation cost theory. The lower accuracy of forecast for companies with higher managerial owners is perhaps can be explained by the 
optimistic behavior of managers in providing positive signal to the market during IPO process.

\section{REFERENCES}

[1] R. Jelic, B. Saadouni, and R. Briston, "The accuracy of earnings forecasts in IPO prospectuses on the Kuala Lumpur Stock Exchange," Accounting and Business Research, vol. 29, pp. 57-72, 1998.

[2] N. Ismail and P. Weetman, "Forecast accuracy in initial public offerings and the impact of external constraints relative to managerial choice: A research note," Accounting and Finance, vol. 47, pp. 513-525, 2007.

[3] S. Claessen, S. Djankov, and L. H. P. Lang, "The separation of ownership and control in East Asian corporations," Journal of Financial Economics, vol. 58, pp. 81-112, 2000.

[4] R. L. Porta, L. D. S. Florencio, and A. Shleifer, "Corporate ownership around the world," The Journal of Finance, vol. 54, pp. 471-517, 1999.

[5] SC rejects over half of 51 IPO plans in Jan-June, News Strait Times, ed. Malaysia, 2006.

[6] P. Brown, A. Clarke, J. C. Y. How, and K. Lim, "The accuracy of management dividend forecasts in Australia," Pacific-Basin Finance Journal, vol. 8, pp. 309-331, 2000.

[7] D. Gounopoulos, "Associations between management forecast accuracy and pricing of IPOs in Athens stock exchange," Multinational Finance Journal, vol. 15, pp. 235-272, 2011.

[8] J. Sun and G. Liu, "The impact of the CSRC Regulation No. 12-1996 on the credibility of Chinese IPO earnings forecasts," Global Finance Journal, vol. 20, pp. 165-179, 2009.

[9] M. Firth and A. Smith, "The accuracy of profit forecasts in initial public offering prospectuses," Accounting and Business Research, vol. 22, pp. 239-247, 1992.

[10] V. Jog and B. J. McConomy, "Voluntary disclosure of management earnings forecasts in IPO prospectuses," Journal of Business Finance and Accounting, vol. 30, pp. 125-167, 2003.

[11] M. Firth, B. C. H. Kwok, C. K. L. Tan, and G. H. H. Yeo, "Accuracy of profit forecasts contained in IPO prospectuses," Accounting and Business Review, vol. 2, pp. 58-83, 1995

[12] C. L. Chin, G. Kleinman, P. Lee, and M. F. Lin, "Corporate ownership structure and accuracy and bias of mandatory earnings forecasts: Evidence from Taiwan," Journal of International Accounting Research, vol. 5, pp. 41-62, 2006.

[13] R. Jelic, B. Saadouni, and R. Briston, "Performance of Malaysian IPOs Underwriters reputation and management earnings forecasts," Pacific-Basin Finance Journal, vol. 9, pp. 457-486, 2001.

[14] N. A. A. Zaluki and W. N. W. Hussin, "Corporate governance and earnings forecasts accuracy," Asian Review of Accounting, vol. 18, pp. $50-67,2010$

[15] B. Ajinkya, S. Bhojraj, and P. Sengupta, "The association between outside directors, institutional investors and the properties of management earnings forecasts," Journal of Accounting Research, vol. 43, pp. 343-376, 2005.

[16] H. H. Huang, M. L. Chan, C. H. Chang, and J. L. Wong, "Is corporate governance related to the conservatism in management earnings forecasts?" Emerging Markets Finance \& Trade, vol. 48, pp. 105-121, 2012.

[17] N. Ismail, "Earnings management and forecast accuracy: A study of Malaysian initial public offerings," Doctor of Philosophy, Department of Accounting and Finance, University of Strathclyde, UK, 2007.

[18] H. I. Bulut and B. Er, "The accuracy of earnings forecasts disclosed in PO prospectuses: The case of the Turkish IPO companies," METU Studies in Development, vol. 37, pp. 221-245, 2010.

[19] Securities Commission, FAQs on Prospectus Guidelines - Enhanced Financial Disclosure Requirements, S. Commission, Ed., ed, 2008.
[20] T. E. Cooke, "Regression analysis in accounting disclosure studies," Accounting and Business Research, vol. 28, pp. 209-224, 1998

[21] M. T. A. E. Rajabi and A. Gunasekaran, "The accuracy of earnings forecasts disclosed in the prospectuses of newly formed public companies in Jordan," Managerial Auditing Journal, vol. 21, pp 117-131, 2006

[22] Y. Hutagaol, D. L. Warganegara, and C. Wibisono, "The accuracy of earnings forecast and post-IPO earnings management," in International Conference on Management, Economics and Finance (ICMEF 2012), Hilton Hotel, Kuching, Sarawak, Malaysia, 2012, pp 183-197.

[23] R. Lonkani and M. Firth, "The accuracy of IPO earnings forecasts in Thailand and their relationships with stock market valuation," Accounting and Business Research, vol. 35, pp. 269-286, 2005

[24] S. Y. Foong and S. C. Loo, "Earnings forecast accuracy and bias in initial public offerings in Malaysia," Singapore Management Review, vol. 12, pp. 89-108, 1999.

[25] S. A. Mohamad, T. Nassir, K. Kuing, and M. Ariff, "The accuracy of profit forecasts of Malaysian IPOs," Capital Markets Review, vol. 31, pp. 46-69, 1994.

[26] D. Wang, "Founding family ownership and earnings quality," Journal of Accounting Research, vol. 44, pp. 619-656, 2006.

[27] J. P. H. Fan and T. J. Wong, "Corporate ownership structure and the informativeness of accounting earnings in East Asia," Journal of Accounting and Economics, vol. 33, pp. 401-425, 2002.

[28] M. J. Barclay, C. G. Holderness, and J. Pontiff, "Private benefits from block ownership and discounts on closed-end funds," Journal of Financial Economics, vol. 33, pp. 263-291, 1993.

[29] N. A. Hartnett and J. Romcke, "The predictability of management forecast error: A study of Australian IPO disclosures," Multinational Finance Journal, vol. 4, pp. 101-132, 2000.

[30] J. Bedard, D. Coulombe, and L. Courteau, "Audit committee, underpricing of IPOs and accuracy of management earnings forecasts," Corporate Governance: An International Review, vol. 16, pp. 519-535, 2008.

[31] L. Chapple, P. M. Clarkson, and C. J. Peter, "Impact of the Corporate Law Economic Reform Program Act 1999 on initial public offerings prospectus earnings forecasts," Accounting and Finance, vol. 45, pp 67-94, 2005.

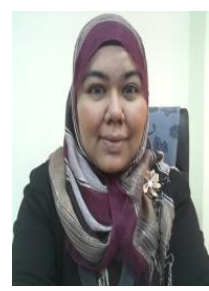

Noor Ayuernie Ibrahim is a Ph.D. Candidate under Universiti Teknologi MARA, Malaysia. She received her Master of Accountancy from the Universit Teknologi MARA, Malaysia in 2010. She has been awarded a "Young Lecturer Scheme Scholarship" by Ministry of Education of Malaysia for her PhD. She has attended more than three national and international conferences and has been awarded a FRGS research grant under Ministry of Higher Education (MOHE) Her area of research includes financial reporting.

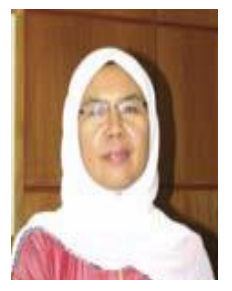

Norashikin Ismail is an associate professor at the Faculty of Accountancy, Universiti Teknologi MARA (UiTM), Malaysia. She received her $\mathrm{PhD}$ in Accounting from the University of Strathclyde, UK. Her area of research includes financial reporting. Her works has been published in Accounting and Finance (Wiley), Journal of Financial Reporting and Accounting, and The Journal of American Academy of Business, Cambridge. 